\title{
JRA-55にもとづく長期波浪推算と 波候特性の解析
}

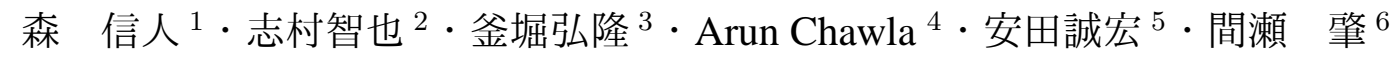 \\ 1正会員 博（工）京都大学准教授 防災研究所（－ $611-0011$ 京都府宇治市五ヶ庄） \\ E-mail: mori@oceanwave.jp \\ 2 正会員 博（工）京都大学特別研究員 防災研究所（ $\bar{T}$ 611-0011 京都府宇治市五ケ庄） \\ E-mail: shimura.tomoya@gmail.com \\ 3 正会員 博 (工) 気象研究所室長 気候研究部（３05-0052 茨城県つくば市長峰 1-1） \\ E-mail: hkamahor@mri-jma.go.jp \\ ${ }^{4}$ Ph.D, NOAA, Leader Marine Modeling and Analysis Branch (5830 University Research Court, College Park, MD 20740, USA) \\ E-mail: arun.chawla@noaa.gov \\ 5 正会員 博（工）京都大学助教 防災研究所（ ₹ 611-0011 京都府宇治市五ケ庄） \\ E-mail: yasuda.tomohiro.4x@kyoto-u.ac.jp \\ 6 正会員 工博京都大学准教授防災研究所（７ 611-0011 京都府宇治市五ケ庄） \\ E-mail: mase.hajime.5c@kyoto-u.ac.jp
}

\begin{abstract}
気象庁が開発した 55 年間の大気再解析值 JRA-55 をもとに, 波浪の長期推算を行った。波浪推算は, スペク トル型波浪モデル WAVEWATCHIII の 2 種類のソース項の組み合わせを用いて行った. 得られた波浪推算結果を ブイおよび衛星高度計の観測值と比較検証し，ERA-40/Interrimに比べて平均波高および極大波高について良い 精度を持つことを明らかにした. また年最大有義波高等の極大波浪についても，JRA-55 の推算精度は高く，熱 帯低気圧の発生域を除くと JRA-55 にもとづく極值分布は, 観測值にかなり近い分布形状を示すことを明らかに した.
\end{abstract}

Key Words: JRA-55, long-term analysis, spectral wave model, wave climate, WAVEWATCH III

\section{1. 序 論}

海岸構造物の設計においては，長期の波浪観測資料 にもとづき対象海域の設計波高が算定されるが，必ず しも対象海域の波浪観測資料があるわけではないため, それを補うために波浪推算が行われることが多い。こ のような長期の波浪推算においては, 波浪モデルの計 算精度以外にも, 対象海域に高波をもたらす気象擋乱 をできるだけ長期間にわたり多く取り上げること，その 気象条件に対して精度の良い風データを用いることが 重要である。このため, NCEP/NCAR, ERA-40/Interim など, 大気再解析值を用いた長期の波浪推算が行われ てきた ${ }^{1), ? \text {. }}$.

一方, 地球温暖化による海岸・海洋の将来変化予測お よびその影響評価研究が精力的に進められており，2013 年に発表された IPCC 第 5 次報告書（AR5）第 1 作業 部会では, 全球気候モデルを用いた平均波高の将来変 化について報告されており ${ }^{2)}$, 日本周辺では将来の平 均波高が減少することが予測されている3),10),11). 過去 の波候変化については，ここ 40 年間で北大西洋の年間 最大波高は $5 \mathrm{~cm} / \mathrm{year}$ の増加傾向があると報告されてい $3^{4)}$. 大西洋を対象とした幾つかの長期波浪推算結果
は, カナダ東海岸およびアイルランド北西における増 加傾向とスカンジナビア沖および北海における弱減少 の 2 つの異なる傾向を示している ${ }^{4)}$. 気象の長期再解 析データは, 長期間に全球を網羅する地上変数を含ん でおり, 工学的に応用範囲が広い, 大気再解析值を用 いた過去の平均波高のトレンド解析においては, 大気 再解析值自体が均質でデータ同化等に依存した人工的 なトレンドを持っていないことが必要である5 ${ }^{5}$. また, 極大波高の長期評価に対しては, 台風などの局所的な 極端現象が考慮されている必要がある.JRA-55(6),7) は 55 年間という長期間かつ高解像度な気候再解析であり, 海岸工学への応用が期待される.

本研究では, JRA-55 を外力として, スペクトル型波 浪モデルを用いた全球の長期波浪推算を実施し, 精度 検証を行った。ついで得られた結果の詳細な解析を行 い，波浪特性の長期変動特性について明らかする.

\section{2. 研究手法の概要}

長期波浪推算は, JRA- $\left.55^{7}\right)$ の高度 $10 \mathrm{~m}$ 風速 $\left(U_{10}\right)$ を外力として, NOAA が開発した WAVEWATCH III (ver. 4.18) を用いて実施した。うねりの推算精度評価の 
ために，波浪モデルのソース項の組み合わせを TolmanCharikov (1996) の組み合わせ ${ }^{8)}$ （以下 ST2 と表記）と Ardhuin et al. (2010) の組み合わせ 9)（以下 ST4 と表記） の 2 種類を用いて波浪推算を実施した. ST2 は，長く 使われてきた WAVEWATCH III ver.3.x と同じソース項 の組み合わせであり, ST4 は特に $S_{i n}$ と $S_{d s}$ について のチューニングが行われたものである.

波浪の計算条件は，計算期間は JRA-55 と同じ 1958 年から 55 年間, 計算範囲は全球を対象とした。また, 空間解像度は JRA-55 と同じ約 $60 \mathrm{~km}$, 時間解像度は 1 時間であり, 海底地形は米国地球物理データセンター （NGDC）のデジタル地勢データETOPO5を用い，300m 以深は深海条件として計算した，方向スペクトルの周 波数分割数は 29 , 方向分割数は 36 (10 度刻み) 標準的 な設定を用いた。さらに，JRA-55 で使用された観測海 水分布データを用いて, 極域の海水についても波浪推 算で考慮した。

波浪計算の外力である JRA-55 の $U_{10}$ と波浪推算結果 の代表統計量である有義波高 $H_{s}$ および有義波周期 $T_{s}$ の計算精度については, 洋上の長期観測データ（以下ブ イデータ）およびESA GlobWaveによる衛星高度計デー タとの比較検証した．長期間の波浪推算精度を評価する ため，比較に用いたブイデータは， $50 \mathrm{~m}$ 以上の水深で 20 年以上の観測期間を持つものとして, 気象庁の沿岸 波浪計データ 6 地点と NOAA の NDBC (National Data Buoy Center) の洋上ブイ 31 地点の合計 37 地点のデータ を用いた．また類似の先行研究である ERA-40/Interim の $U_{10}$ および波浪代表統計量についても比較した。な お平均波高については ERA-40，極大波高については ERAのデータと比較した (以下では単に ERA と示す).

\section{3. 精度の検証}

\section{(1) 大気場}

紙面の関係上, 大気場, 特に $U_{10}$ の推算精度の検証結 果については詳しく述べないが，JRA-55 の $U_{10}$ の月平 均值は, ERAに比べると極域でやや大きく, 年最大值 等の極大值についても熱帯低気圧の影響海域で大きな 值となっている．観測データと比較した結果, JRA-55 の極大風速の精度は, ERA 等と比較して良い精度を持 つことをがわかった。

\section{（2）波浪推算精度}

月平均有義波高 $H_{s}^{m}$, 年最大波高 $\left\langle H_{s}^{\max }\right\rangle$ (以下極大 波高), 月平均有義波周期 $T_{s}^{m}$ 等についての精度検証を 行った. 図-1に示すのは, 期間平均波高 $\left\langle\left\langle H_{s}^{m}\right\rangle\right\rangle$ の比 較である.JRA-55(ST4) と ERA は空間分布は非常に似 ているものの, ERA は中・高緯度帯での波高が小さく,

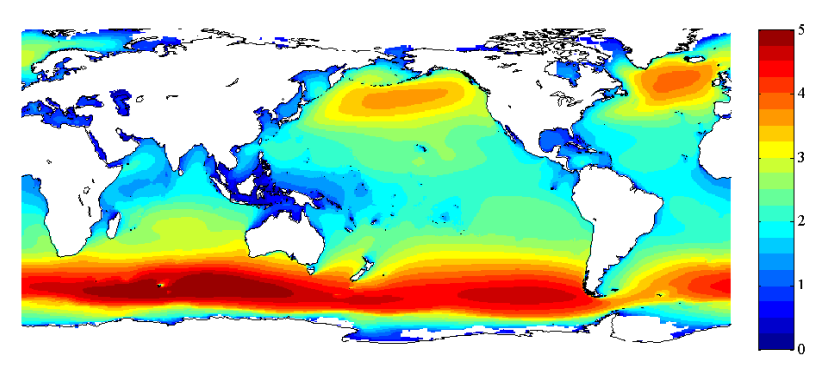

(a) JRA-55 (ST4)

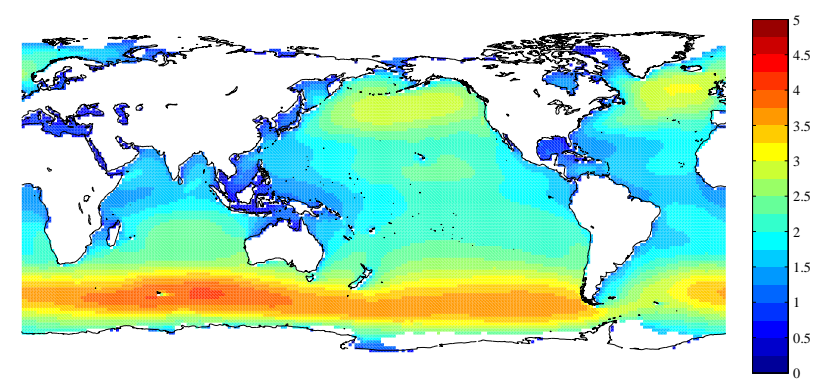

(b) ERA

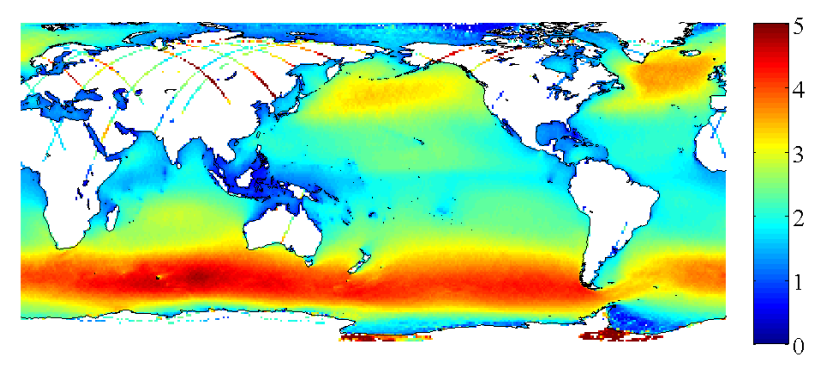

(c) GlobWave

図-1 期間平均波高 $\left\langle\left\langle H_{s}^{m}\right\rangle\right\rangle$ の比較. それぞれ期間長が異な る. (単位:m)

また北西太平洋低緯度帯における空間分布も若干異な る特徵がある. GlobWave による $\left\langle\left\langle H_{s}^{m}\right\rangle\right\rangle$ は, 北太平洋 においいてやや過小評価であるものの, 低緯度帯や南 極海での空間分布および絶対值は JRA-55(ST4) に近い. これらの結果, JRA-55(ST4) は, ERAに比べて, 平均 波高の分布形状および絶対值共に適合度が高く, 推算 精度が良いことがわかった。

つづいて月平均有義波高 $H_{s}^{m}$, 年最大波高 $\left\langle H_{s}^{\max }\right\rangle$ の推算精度について, ブイ観測データとの比較を行っ た. 図-2に示すのは, 月平均波高 $H_{s}^{m}$ の計算精度であ る. 図中の記号の位置はブイの位置を示し, 記号はそ れぞれ る結果を示す. GlobWave との比較同様に, ERAに比べ て JRA-55 の誤差は全体的に小さい. 東太平洋および大 


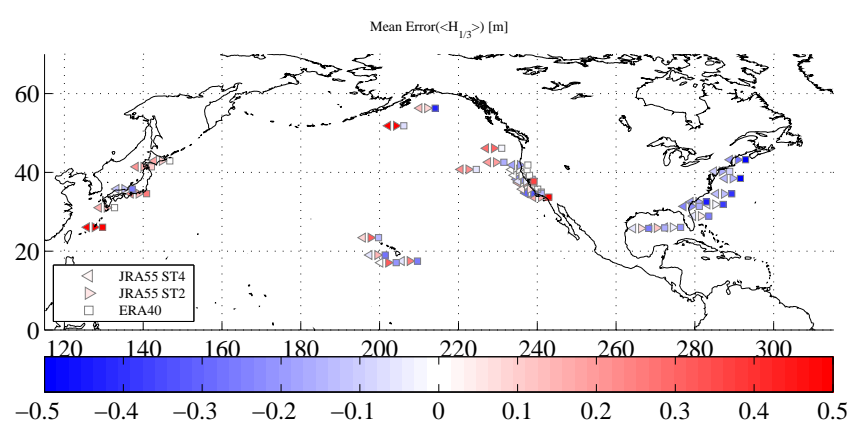

(a) 平均誤差

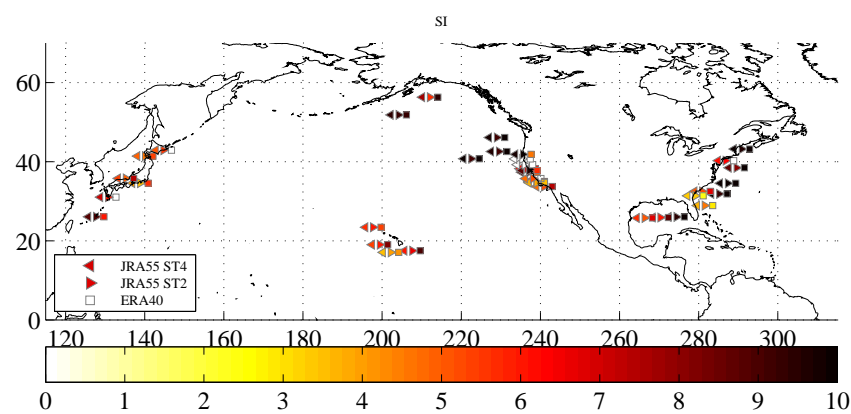

(b) Scatter Index

図-2 ブイデータと比較した月平均波高 $H_{s}^{m}$ の精度. 図中 の記号の位置はブイの位置を示し, 記号はそれぞれ JRA-55(ST4), ஓ: JRA-55(ST2), $\square:$ ERA による結果

西洋では，JRA-55 および ERA 共に過小評価であるが， 日本周辺では JRA-55 がやや過大, ERA は過小評価と なっている.これは, 図-1に示したように, 北太平洋 中高緯度における波高の分布特性と一致した傾向であ る.一方で，Scatter Index については，全域でJRA-55 の值は良く, バイアスについては空間的に不均一であ るが，誤差の割合としては一貫して小さいことがわかっ た。特に観測点全体の平均誤差は大きく改善されてお り，特に中緯度台風影響域の精度向上が顕著であった。

ついで，年々変動などの長期的な時系列特性につい ても検証を行った．図-3に示すのは，アラスカ沖とハ ワイ沖のブイ観測地点における年平均波高 $\left\langle H_{s}^{m}\right\rangle$ と年 最大波高 $\left\langle H_{s}^{\max }\right\rangle$ の時間変化である. $\left\langle H_{s}^{m}\right\rangle$ について は, ERA の結果が観測データと比較してやや過小評価 であるのに対し，JRA-55 の結果は観測データとよく一 致している. またアラスカ沖に比べてハワイ沖におい て, JRA-55(ST2)の結果は, JRA-55(ST4) よりもやや詔 差が大きいという特徴がみられる。一方, $\left\langle H_{s}^{\max }\right\rangle に つ$ いては, 観測值と比較して, ERA の結果がやや過小評 価でかつ年々変動パターンも一致していないが，JRA55 の結果の整合性が良い。これらの特徴は，比較した

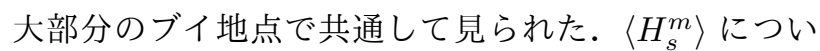
ては，長期観測データとの比較より，ERA と比較して JRA-55(ST4)の結果は, 全球でバイアス等の誤差が改

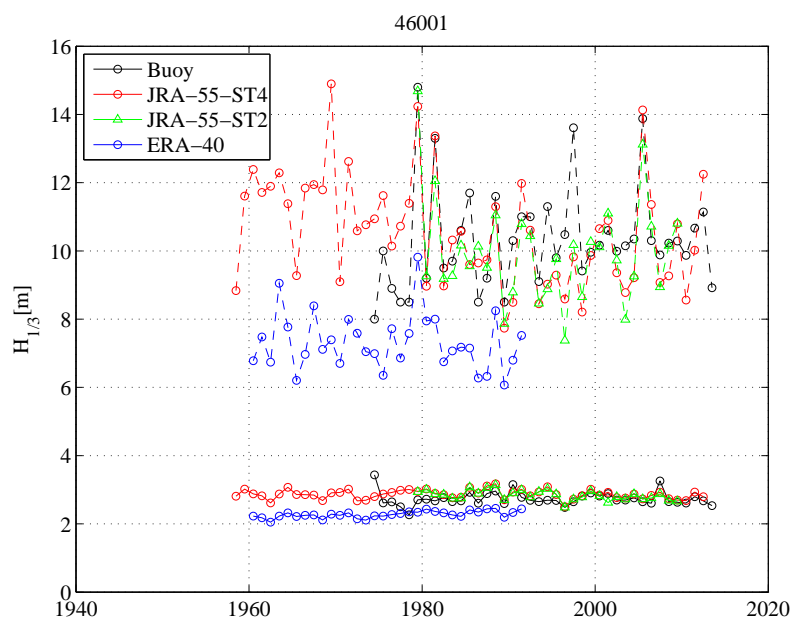

(a) アラスカ沖 : \#46001

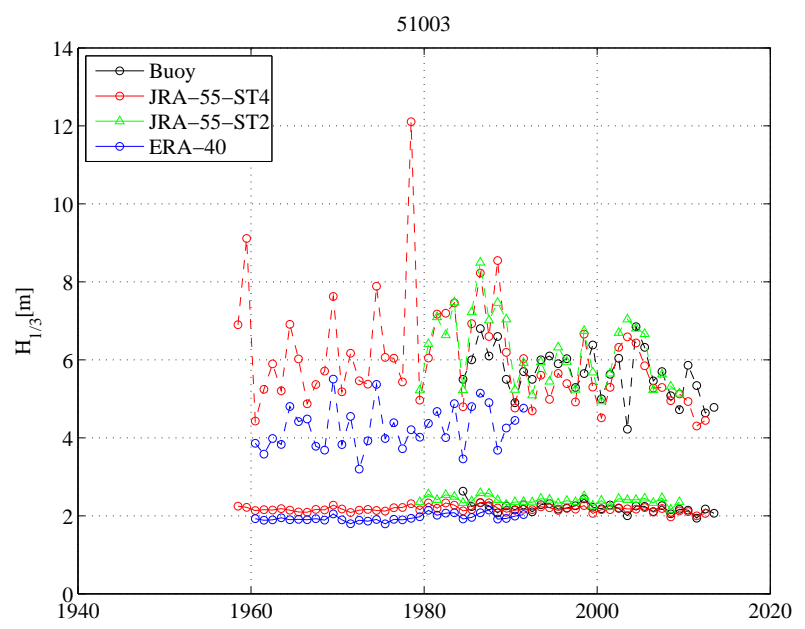

(b) ハワイ沖 : \#51003

図-3 年平均波高 $\left\langle H_{s}^{m}\right\rangle$ と年最大波高 $\left\langle H_{s}^{\max }\right\rangle$ の時間変化とブ イデータとの比較（実線： $\left\langle H_{s}^{\max }\right\rangle$, 点線: $\left\langle H_{s}^{m}\right\rangle$, 黒 $\bigcirc$ : ブイデータ, 赤 $\bigcirc: \mathrm{JRA}-55(\mathrm{ST} 4)$, 緑 $\triangle: \mathrm{JRA}-55(\mathrm{ST} 2)$, 赤 $\bigcirc:$ ERA）

善しており，平均 RMS 誤差は $0.25 \mathrm{~m}$ であった。また， JRA-55(ST4) の結果は, 平均的な誤差だけでなく, 年変 動についても良い推算精度を持つことがわかった。

時系列変化と同様に, 年最大波高 $\left\langle H_{s}^{\max }\right\rangle$ にもとづく の極值分布と推定精度についても評価を行った. 図-4に 示すのは，代表例として図-3 と同じ観測地点における 極值分布の比較である．比較地点にも依存するが，観測 值と比較して，JRA-55による極大波高は，再現期間 10 年の確率波高程度までの整合性は高い。特に，図-4 (a) に示すように，熱帯低気圧の発生域を除くと JRA-55に もとづく極值分布は，観測值にかなり近い分布形状を示 す．またJRA-55(ST4) による極值分布は，JRA-55(ST2) によりも若干観測值に近い分布形状を示す。一方, ERA の結果は明らかに過小評価であり, 1 年再現波高で 1 割 


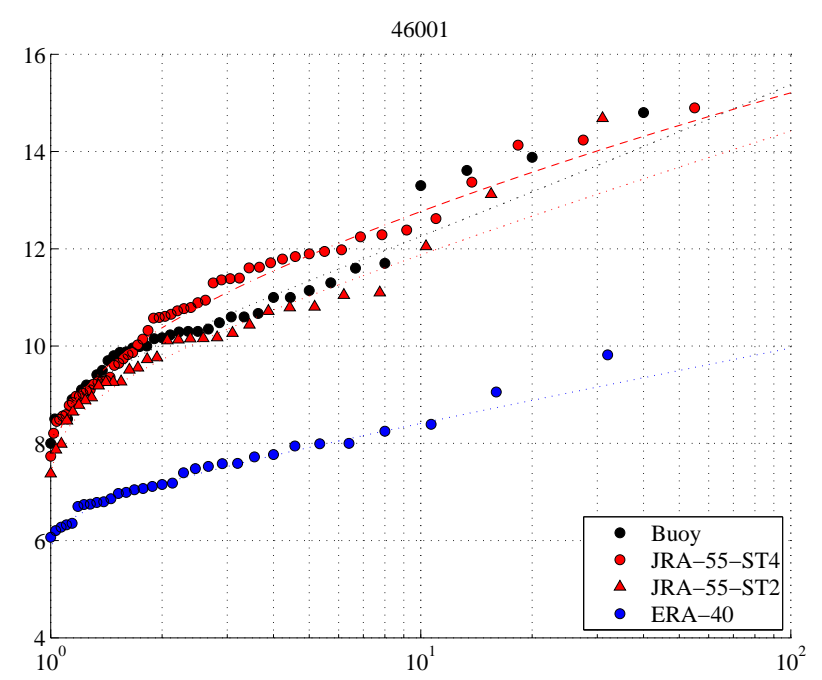

(a) アラスカ沖 : \#46001

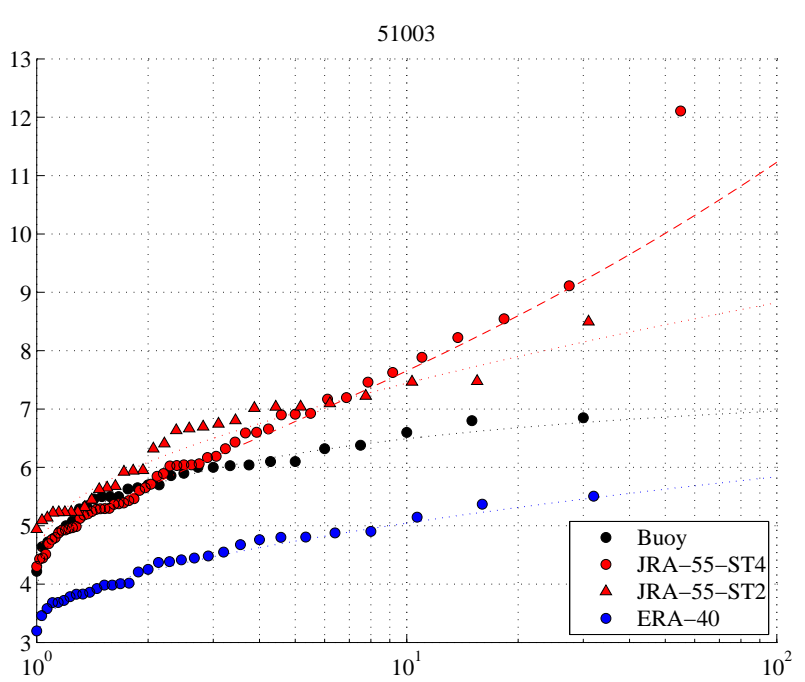

(b) ハワイ沖 : \#51003

図-4 年最大波高 $\left\langle H_{s}^{\max }\right\rangle$ の極值分布とブイデータとの比較 (記号 : 年最大值資料, 点線：推定された分布，黒 : ブイデータ，赤○：JRA-55(ST4)，赤 $\boldsymbol{A} ： \mathrm{JRA}-55(\mathrm{ST} 2)$, 青○ : ERA)

以上值が小さい，極值分布の ERA の誤差は，再現年数 の増加とともに増加傾向がある.

\section{4. 波候特性の解析}

前節までの検討結果より，これまでの長期波浪推算 結果と比較して, JRA-55による平均波高および極大波 高の推定精度が良いことがわかった．ST4の 1 つの特 徵は，うねりの推算精度の向上であり ${ }^{9)}$ ，そこで月平 均波高 $H_{s}^{m}$ と月平均周期 $T_{s}^{m}$ の関係についての解析を 行った. 図-5に示すのは, JRA-55(ST4) および (ST2)の 各月の $H_{s}^{m}$ と $T_{s}^{m}$ の関係を $k$ 平均クラスター分析した 結果であり, 図の (a) および (b) は, 類似度で分類した

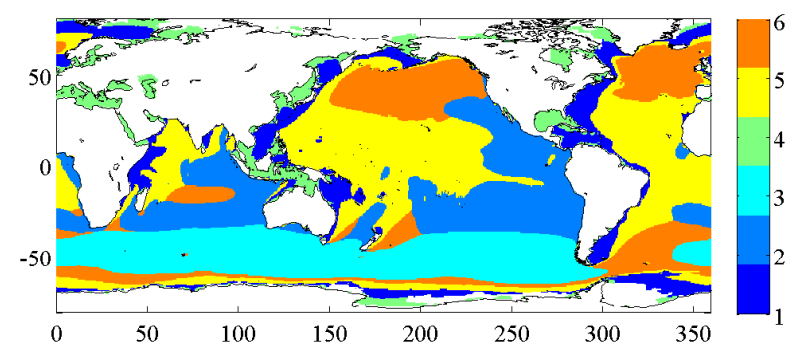

(a) JRA-55 (ST4)

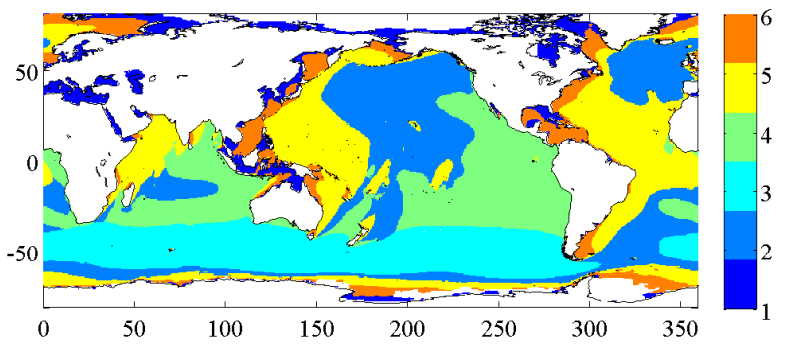

(b) JRA-55 (ST2)

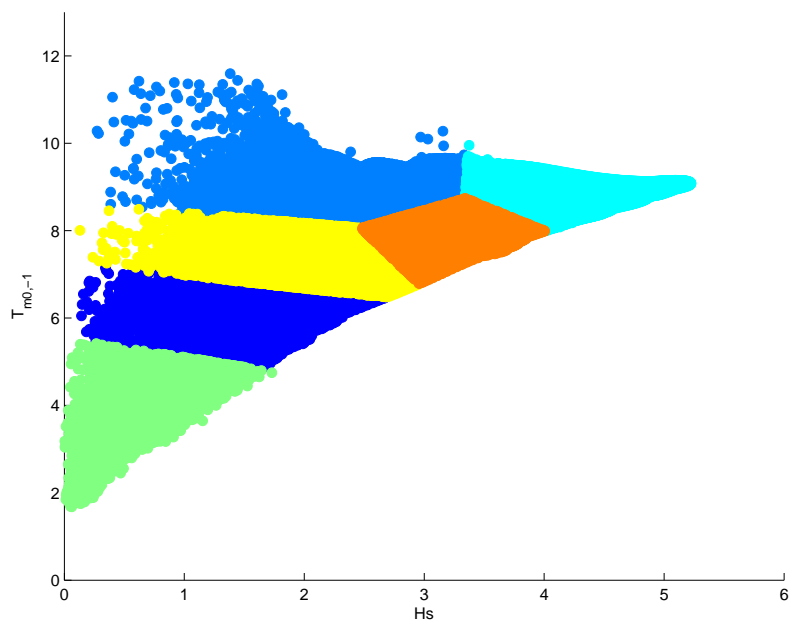

(c) JRA-55 (ST4) の $H-T$ のクラスター分析結果

図-5 月平均波高 $H_{s}^{m}$ と月平均周期 $T_{s}^{m}$ のクラスター分析結 果と空間分布の関係

空間分布であり，(c) は，JRA-55(ST4) についてクラス ター分析された $H_{s}^{m}$ と $T_{s}^{m}$ の分類である (JRA-55(ST2) の分類結果は省く. 図 (a) と (b) の分類は異なる点に注 意). $H_{s}^{m}$ と $T_{s}^{m}$ を 6 分類した場合, JRA-55(ST4) およ び (ST2) では, 南太平洋におけるクラスター分けされ た空間分布が大きく異なることがわかる. 特に月平均 周期 $T_{s}^{m}$ が長い, つまりうねりが割合が大きい赤道域 では, 両者の差異は大きく，南極海やインド洋などの 短いフェッチもしくは風波が支配的な海域での差は小さ い. ERAのクラスター分析結果は, JRA-55(ST2) に近 い傾向を示す. 


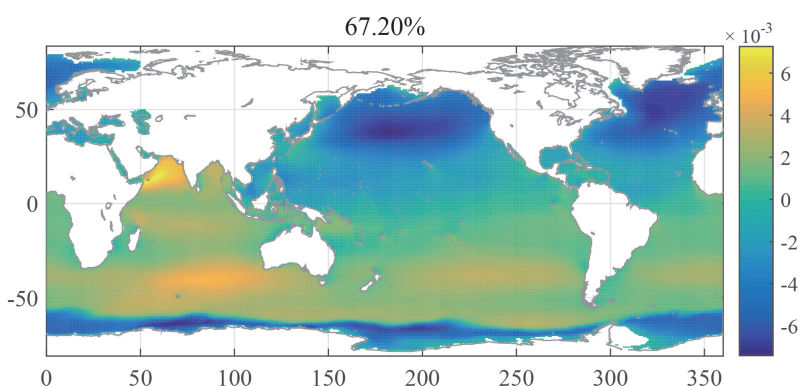

図-6 月平均波高 $H_{s}^{m}$ に対する主成分分析の第 1 モードの分 布 (JRA-55 (ST4))

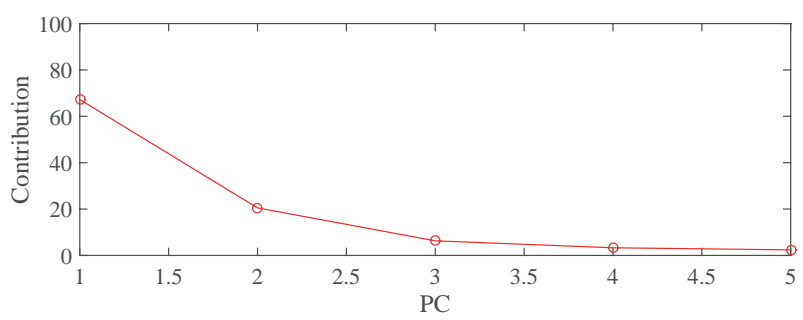

(a) モードの寄与率

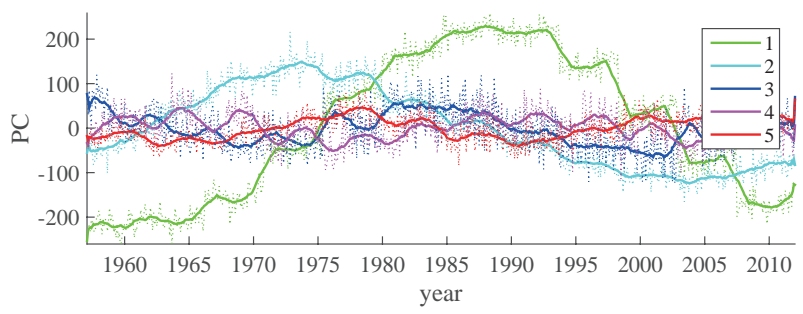

(b) 各モードの時間変化

図-7 月平均波高 $H_{s}^{m}$ に対する主成分分析のモードの寄与率 と時間変化（JRA-55 (ST4)）

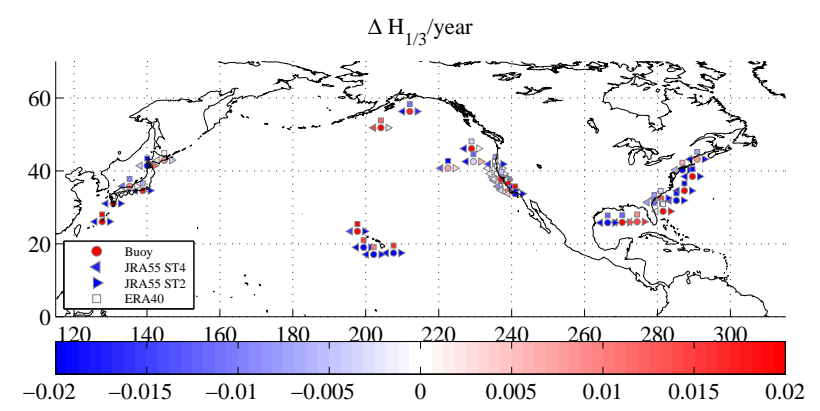

図-8 月平均波高 $H_{s}^{m}$ の変化率の検証（ $\bigcirc:$ ブイデータ, $\triangleleft$ : JRA-55(ST4), $\triangleright:$ JRA-55(ST2), $\square$ : ERA, 単位 : $\mathrm{m} / 10 \mathrm{year}$ )

JRA-55 にもとづく波浪推算結果，特に ST4 の計算結 果が，平均波高および周期についても良好な推算精度 を持つことがわかったため, 推算された長期波浪デー タをもとに, $H_{s}^{m}$ の長期変動（以下変動）と温暖化影 響によるトレンドについて解析を行った，時間・空間 変動特性（以下変動）については主成分分析，長期卜 レンドについては線形回帰を用いて評価を行った。以

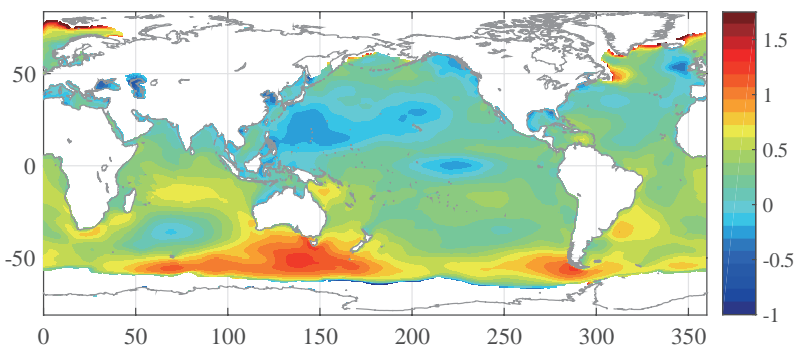

図-9 月平均波高 $H_{s}^{m}$ の変化率 (JRA-55(ST4), 単位: $\mathrm{mm} /$ year)

下では，紙面の関係上，JRA-55(ST4) に対する解析結果 のみを示す.

まず，図-6に示すのは，月平均波高 $H_{s}^{m}$ に対する主 成分分析の第 1 モードの分布である. 第 1 モードの空 間分布は，南極海の陸近傍を除くと図-1に示した平均 波高の空間分布と非常に似ている。主成分分析で表さ れる年々変動については, 図-7に示すように, 主成分 の 3 成分の寄与が支配的であり, 第 1 から第 3 モード の寄与率は $65.4 \%, 21.1 \%, 6.1 \%$ ある. 特に図-6に示 した第 1 モードは, 房総半島付近を挟んで東西で符号 が逆転しており, 日本周辺の領域スケールでも, 変動成 分の日本沿岸への寄与が海域に依存することがわかっ た。また ST4 はST2 に比べて西太平洋における波候特 性が大きく異なり, ソース項により波候特性が大きく 変化する. また, 主成分分析のモードの時間変化より, 数十年以上の変動である第 1 および第 2 モードに続く, 第 3 モードが 5 年から 10 年の変動成分を多く持つこと がわかった。

最後に, 格子点毎に解析した長期トレンドについて 議論する. 図-8に示すのは, 月平均波高 $H_{s}^{m}$ の線形卜 レンドの検証結果である。比較した北太平洋および北 大西洋の大部分の海域で, 観測值が増加傾向を示して いるのに対し, JRA-55 の計算結果は減少傾向を示して いる. 一方, ERA の解析結果は両者の中間に近く, 地 点毎に増加・減少が変化している，観測值をもとにし た長期トレンドは， $\pm 2 \mathrm{~mm} /$ year と海面上昇とほぼ同 じオーダーの変化率を示している. 図-9に示すのは, JRA-55(ST4) で求められた長期トレンドの空間分布で ある.JRA-55(ST4) が示す長期トレンドは, 北西太平洋 および北大西洋における減少傾向と南氷洋における増 加傾向である. 図-8 で示したように，JRA-55(ST4) が 示す推定された過去の平均波高の長期トレンドは土 1〜 $2 \mathrm{~mm} /$ year であり,

ブイの観測值の整合性は低いものの, 空間的なトレ ンド分布はこれまでの温暖化に伴う波高の将来変化予 測 33,10$), 11)$ と一致しており, 将来変化トレンドと整合す るものである.ブイの観測值の整合性については，今 
後の精査が必要である.

\section{5. 結 論}

55 年間という長期間の解析であり，また空間解像度 が約 $60 \mathrm{~km}$ と高解像度である点からも工学的利用価值 が高い JRA-55 をもとに，JRA-55 を外力としてスペク トル型波浪モデルを用いた 55 年間長期解析を実施し, ブイおよび衛星高度計と精度検証を行った。

今回実施した長期波浪推算結果は，ERA-40/Interrim に比べて，平均波高の分布形状および絶対值共に適合 度が高く，推算精度が良いことがわかった。一方，年最 大有義波高等の極大波浪については，JRA-55にもとづ く計算結果は ERA-40/interim と比較して大きな值を示 している．観測結果との比較から，JRA-55 の極大波高 の精度は高く, 主に中緯度帯の台風の再現性度の寄与 が大きなことがわかった。ついで，年々変動などの時 系列についても解析した結果，平均波高だけでなく年 最大波高の年変動についても良い推算精度を持つこと がわかった.さらに, 年最大波高 $\left\langle H_{s}^{\max }\right\rangle$ にもとづく 極值分布についても精度評価を行った結果, 熱帯低気 圧の発生域を除くと JRA-55にもとづく波高の極值分布 は，観測值にかなり近い分布形状を示すことを示した.

以上の結果，今回行った長期波浪解析結果は，これ までの長期解析に比べて良い精度を示しており，また 過去の変動およびトレンドの解析等, 様々な長期波浪 特性の解析に対して有用であることを明らかにした。

謝辞： 本研究は, 文部科学省気候変動リスク情報創生 プログラムおよび科学研究費補助金による成果である.

\section{参考文献}

1) Cox, A. T. and Swail, V. R.: A global wave hindcast over the period 1958-1997, Journal of Geophysical Research, Vol.106, No.C2, pp.2313-2329, 2001.

2) IPCC: IPCC fifth assessment report (AR5) wgi, http://www.ipcc.ch/, 2013.

3) Mori, N., Yasuda, T., Mase, H., Tom, T., and Oku, Y.: Projection of extreme wave climate change under global warming, Hydrological Research Letters, Vol.4, No.0, pp.15-19, 2010.

4) Wang, X. and Swail, V.: Trends of Atlantic wave extremes as simulated in a $40-\mathrm{yr}$ wave hindcast using kinematically reanalyzed wind fields, Journal of Climate, Vol.15, No.9, pp.1020-1035, 2002.

5) Chawla, A., Spindler, D. M., and Tolman, H. L.: Validation of a thirty year wave hindcast using the climate forecast system reanalysis winds, Ocean Modelling, Vol.70, pp.189206, 2013.

6) Ebita, A., Kobayashi, S., Ota, Y., Moriya, M., Kumabe, R., Onogi, K., Harada, Y., Yasui, S., Miyaoka, K., Takahashi, K., et al.: The japanese 55-year reanalysis" jra-55": an interim report, SOLA, Vol.7, pp.149-152, 2011.

7) Kobayashi, S., Ota, Y., Harada, Y., Ebita, A., Moriya, M., Onoda, H., Onogi, K., Kamahori, H., Kobayashi, C., Endo, H., et al.: The jra-55 reanalysis: General specifications and basic characteristics, Journal of the Meteorological Society of Japan, Vol.93, No.1, pp.5-48, 2015.

8) Tolman, H. L. and Chalikov, D.: Source terms in a thirdgeneration wind wave model, Journal of Physical Oceanography, Vol.26, No.11, pp.2497-2518, 1996.

9) Ardhuin, F., Rogers, E., Babanin, A., Filipot, J.-F., Magne, R., Roland, A., Van Der Westhuysen, A., Queffeulou, P., Lefevre, J.-M., Aouf, L., et al.: Semi-empirical dissipation source functions for ocean waves: Part i, definition, calibration and validation, Journal of Physical Oceanography, Vol.40, pp.1917?1941, 2009.

10) Hemer, M. A., Fan, Y., Mori, N., Semedo, A., and Wang, $X$. L.: Projected future changes in wind-wave climate in a multi-model ensemble, Nature Climate Change, p. submitted, 2012.

11) Shimura, T., Mori, N., and Mase, H.: Future projection of ocean wave climate: Analysis of sst impacts on wave climate changes in the western north pacific, Journal of Climate, Vol.28, No.8, pp.3171, 2015.

(2015. 3. 18 受付)

\section{LONG-TERM WAVE HINDCASTS AND WAVE CLIMATE ANALYSIS BY JRA-55}

\section{Nobuhito MORI, Tomoya SHIMURA, Hirotaka KAMAHORI, Arun CHAWLA, Tomohiro YASUDA and Hajime MASE}

This study examined long-term wave hindcasts forced by JRA-55 reanalysis released by Japan Meteorological Agency. The wave hindcasts were performed by new version of WAVEWATCHIII 4.18 with two different configurations, ST2 and ST4 forced by sea surface winds of JRA-55. The mean and extreme significant wave heights show good agreement with observed data by buoys and satellite altimeter. The results of wave hindcasts based on JRA-55 performs better than existing wave reanalysis as ERA-40 and ERA-interim. The extreme value analysis for wave heights are agree with observed data in the mid-latitude except active tropical cyclone regions. 